\title{
Management of Takotsubo cardiomyopathy before non-cardiac surgery: A case report
}

\author{
Kardiyak dışı cerrahi öncesinde Takotsubo kardiyomiyopatisi yönetimi: Olgu sunumu \\ Tayfun Gürol 1
}

Department of Cardiology, Bahçeşehir University Medical Park Göztepe Hospital, Istanbul, Turkey

\begin{abstract}
Takotsubo cardiomyopathy (left ventricular apical balloon syndrome) is characterized by transient apical ballooning, leading to apical systolic dysfunction. This syndrome typically mimics acute coronary syndrome in terms of electrocardiographic changes and cardiac enzyme release. Although its exact pathophysiology is still unclear, it is thought to be due to stress related to the catecholaminergic discharge. It is usually seen on postmenopausal women. Herein, we report a 78 -year-old female patient with Takotsubo cardiomyopathy admitted to the orthopedic surgery clinic due to a femoral fracture and had no complication after surgery.
\end{abstract}

Keywords: Acute coronary syndrome, angina, Takotsubo cardiomyopathy, stress.

In 1990, Takotsubo cardiomyopathy (TTC) was first reported in Japan. ${ }^{[1,2]}$ "Takotsubo" is named of Japanese octopus trap, with a similar shape of the patient's left ventricle (LV) in systole. It is described as a transient reversible cardiomyopathy and typically occurs in older women after emotional or physical stress. ${ }^{[3-5]}$ The presenting characteristics of TTC are similar to those of myocardial ischemia after acute plaque rupture; however, the characteristic distinctions are regional wall motion abnormalities that extend beyond a single coronary vascular bed and the absence of epicardial coronary occlusion. ${ }^{[6,7]}$

Researchers at the Mayo Clinic proposed diagnostic criteria in 2004, which were modified in 2008. All

\section{$\ddot{O} Z$}

Takotsubo kardiyomiyopatisi (sol ventrikül apikal balonlaşma sendromu), apikal sistolik disfonksiyona yol açan geçici apikal balonlaşma ile karakterizedir. Bu sendrom genellikle elektrokardiyografik değişiklikler ve kardiyak enzim salınımı açısından akut koroner sendromu taklit eder. Patofizyolojisi kesin olarak bilinmemekle birlikte, stres kaynaklı katekolaminerjik deşarja bağlı olduğu düşünülmektedir. Genellikle postmenopozal kadınlarda gözlenir. Bu yazıda, femur kırı̆̆ı nedeniyle ortopedik cerrahi kliniğine başvuran ve cerrahi sonrası herhangi bir komplikasyon gözlenmeyen Takotsubo kardiyomiyopatili 78 yaşında bir kadın olgu sunuldu.

Anahtar sözcükler: Akut koroner sendrom, anjina, Takotsubo kardiyomiyopatisi, stres.

four criteria must be met in the Mayo Clinic proposed criteria: ${ }^{[8-10]}$

1. Transient hypokinesis, akinesis, or dyskinesis of the LV midsegments with or without apical involvement; the regional wall motion abnormalities extend beyond a single epicardial vascular distribution; a stressful trigger is often, but not always present.

2. Absence of obstructive coronary disease or angiographic evidence of acute plaque rupture

3. New electrocardiographic (ECG) abnormalities (either ST-segment elevation and/or T-wave inversion) or modest elevation in cardiac troponin 
4. Absence of:

a) Pheochromocytoma

b) Myocarditis.

The last one is the Takotsubo Italian Network (TIN) diagnostic criteria, which were proposed in 2014 as follows: ${ }^{[11]}$

1. Typical transient LV wall motion abnormalities extending beyond a single epicardial vascular distribution with complete functional normalization within six weeks

2. Absence of potentially culprit coronary stenosis, or angiographic evidence of acute plaque rupture, dissection, thrombosis or spasm

3. New and dynamic ST-segment abnormalities or T-wave inversion, as well as new-onset of transient or permanent left bundle branch block

4. Mild increase in myocardial injury markers (creatine kinase-myocardial band [CK-MB] value $50 \mathrm{U} / \mathrm{L}$ ).

5. Clinical and/or instrumental exclusion of myocarditis

6. Postmenopausal woman (optional)

7. Antecedent stressful event (optional)

\section{CASE REPORT}

A 78-year-old female patient had a femoral fracture and was admitted to the orthopedic surgery clinic. As she had dyspnea and chest pain, cardiology consultation was requested. Her medical history

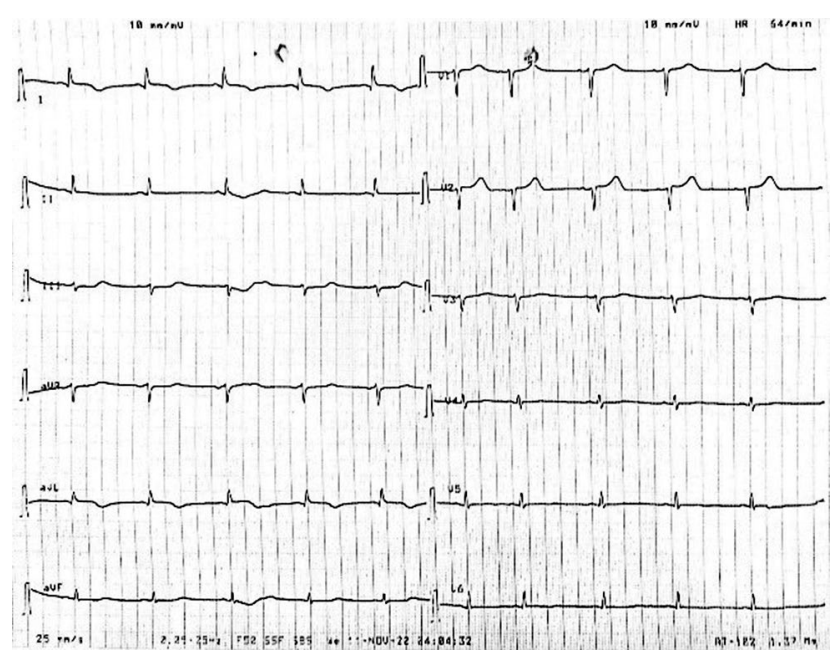

Figure 1. Electrocardiogram showing 1-mm ST elevation on ECG Lead I-aVL and T negativity.

ECG: Electrocardiography. revealed hypertension. On her physical examination, blood pressure was $140 / 90 \mathrm{mmHg}$ and heart rate was $100 \mathrm{bpm}$. She had S1 and S2 heart sounds, but no S3 and S4. She had crepitant rales at both lung bases. Troponin $(2,102 \mathrm{pg} / \mathrm{mL})$ and CK-MB (36.3 U/L) were tested. She was diagnosed with acute coronary syndrome based on the 1-mm ST elevation on ECG Lead I-aVL and $\mathrm{T}$ negativity. Echocardiography revealed dyskinesia in the apical septum and anterior wall with ejection fraction (EF) of 35\%. On coronary angiography, a plaque was seen in left anterior descending (LAD) ostium and proximal of right coronary artery. The circumflex artery was normal (Figures 1-4). Based on these findings, clopidogrel (loading dose: $75 \mathrm{mg}$ eight doses in total daily; maintenance dose: once daily), acetylsalicylic acid (300 $\mathrm{mg}$ once daily), perindopril (5 mg once daily), bisoprolol (5 mg $1 \times 0.5$ ), furosemide ( $40 \mathrm{mg}$ b.i.d.), enoxaparin ( $0.4 \mathrm{~mL}$ b.i.d., subcutaneous), atorvastatin (40 $\mathrm{mg}$ once daily), ivabradine (5 $\mathrm{mg}$ b.i.d.), pantoprazole (40 mg once daily) were started. As she had anxiety, alprazolam was also given. Dyspnea and chest pain resolved and on ECG Lead I-aVL, no ST elevation was seen; however, $\mathrm{T}$ negativity was persistent. In the second day of treatment, the QTc was $600 \mathrm{msec}$ and pantoprazole was discontinued.

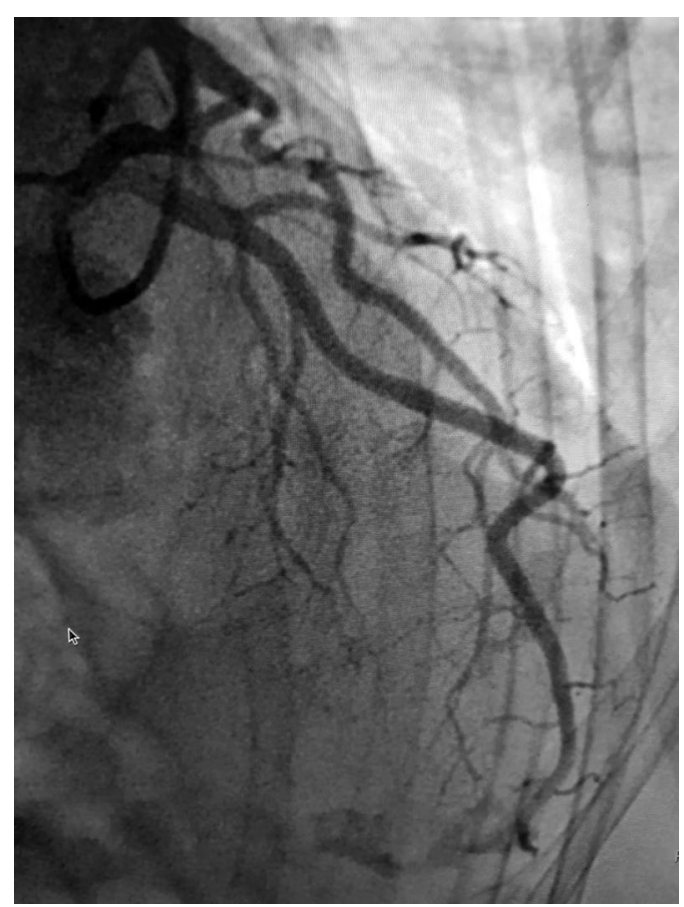

Figure 2. Left coronary artery angiography showing a plaque seen in left anterior descending ostium. The circumflex artery is normal. 


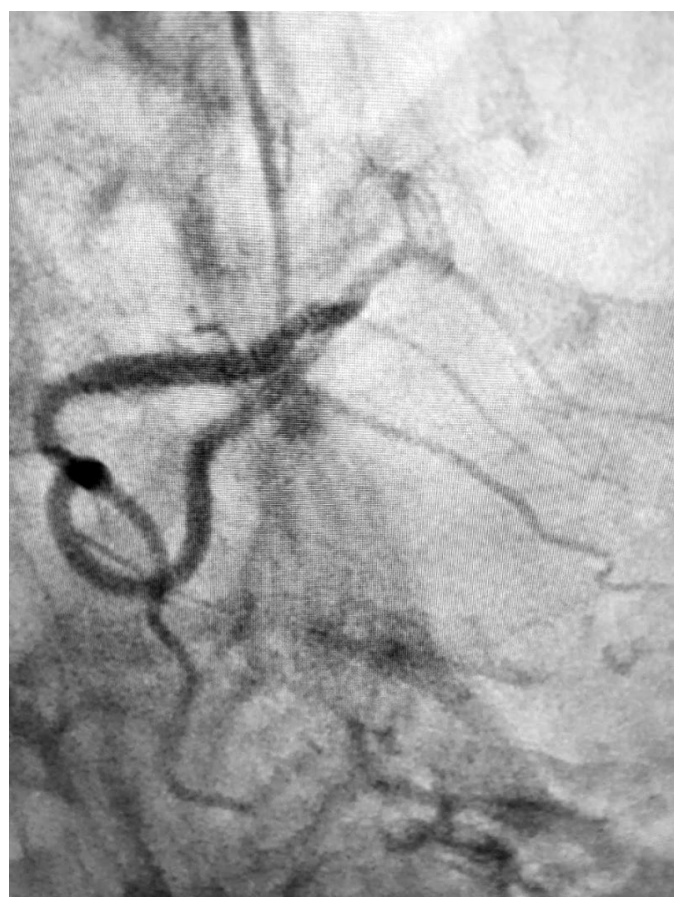

Figure 3. Right coronary artery angiography showing a plaque in proximal of right coronary artery.

In the following days, QTc returned to normal. In the fifth day of medication, normokinetic motion of the septum and apical wall on echocardiography was seen. The EF was measured as 55\%. The reason for acute coronary syndrome was thought as Takotsubo syndrome based on anxiety. The medication was continued and, after seven days, she was transferred to the operating theater for surgical treatment. No peri- and postoperative complication was seen. A written informed consent was obtained from the patient.

\section{DISCUSSION}

It is important to diagnose TTC, which accounts for 3 to $5 \%$ of all mortalities, leading to ventricular arrhythmia, pump failure, heart rupture, and thromboembolic stroke. ${ }^{[12]}$ In addition to the difficulty in diagnosis, its reproducibility increases the importance of this syndrome. Repeated cases are shared in the literature. ${ }^{[13-15]}$

In Turkey, reviews were reported together with case reports on TTC. These cases addressed to the triggering conditions and none of them had a preoperative diagnosis as in our case. Arslan et al. ${ }^{[16]}$ reported that TTC appeared in three of four patients after the operation. They suggested that the increase in catecholamine levels may trigger this. Küçükdurmaz

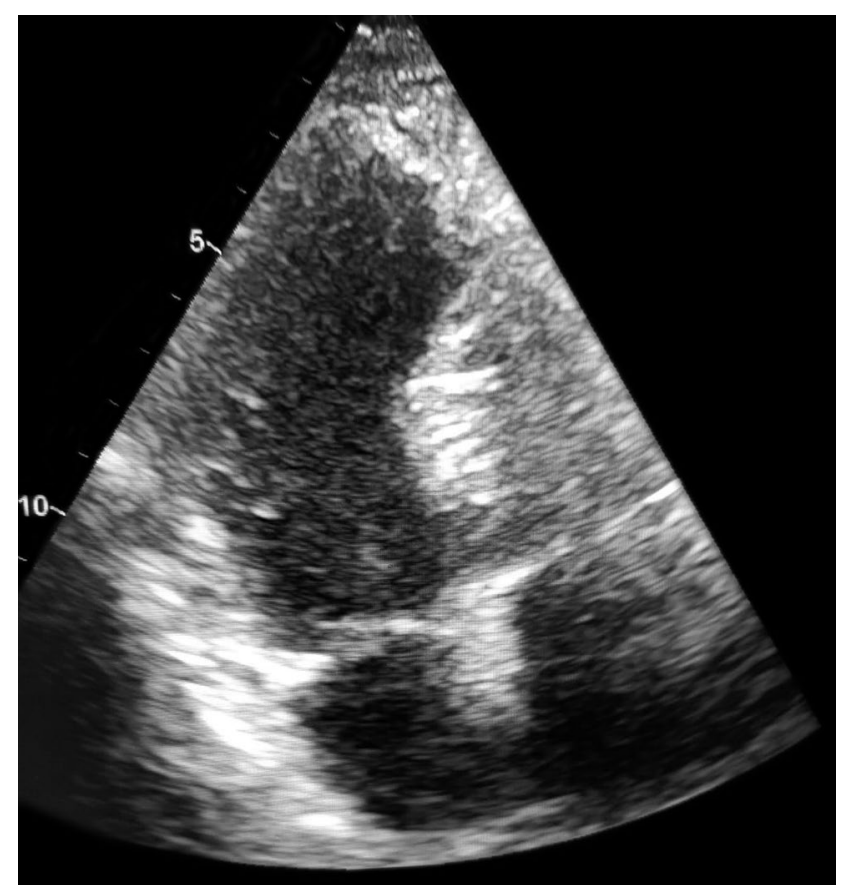

Figure 4. Echocardiography showing apical ballooning.

et al. ${ }^{[17]}$ also reported that four of six patients returned to normal without complications, and two patients admitted with cardiogenic shock and sudden cardiac death died and received cardiopulmonary resuscitation. Deniz et al. ${ }^{[18]}$ reported TTC, which is usually seen in female patients, in a 92-year-old male patient appeared after the operation for a bladder tumor. Yenerçağ et al. ${ }^{[19]}$ also reported the oldest TTC case in the literature and found that the levosimendan treatment given to patients with heart failure could accelerate the recovery period. In another report, Ugurlucan et al. ${ }^{[20]}$ presented a TTC case with thyrotoxicosis and an autoimmune disease.

The difference of this case from other cases reported in the literature is the stress experienced by the patient before femoral surgery as the possible trigger of this syndrome. Accordingly, the managed treatment enabled the patient to undergo surgery without any complications. Another possible reason for QT prolongation in this case was pantoprazole treatment which was discontinued; however, the possibility of this complication due to TTC was considered after the diagnosis.

In conclusion, pathophysiological studies and various case management reports on Takotsubo cardiomyopathy are useful to keep this syndrome in mind in the differential diagnosis. In addition, 
there is no information in the literature regarding the timing for surgery in these patients. In our case, due to a femoral fracture, the patient was operated after a safe period to provide early mobilization. In the management, psychiatric treatment and follow-up are of utmost importance to alleviate anxiety and stress in Takotsubo cardiomyopathy patients. Nonetheless, there should be more experience to tailor the definitive treatment.

\section{Declaration of conflicting interests}

The author declared no conflicts of interest with respect to the authorship and/or publication of this article.

\section{Funding}

The author received no financial support for the research and/or authorship of this article.

\section{REFERENCES}

1. Sato H, Taiteishi H, Uchida T. Takotsubo type cardiomyopathy due to multivessel spasm. In: Kodama $\mathrm{K}$, Haze $\mathrm{K}$, Hon $\mathrm{M}$, editors. Clinical aspect of myocardial injury: from ischemia to heart failure. Tokyo: Kagakuhyouronsya Publishing Co; 1990. p. 56-64.

2. Dote K, Sato H, Tateishi H, Uchida T, Ishihara M. Myocardial stunning due to simultaneous multivessel coronary spasms: A review of 5 cases. J Cardiol 1991;21:203-14. Japanese.

3. Tsuchihashi K, Ueshima K, Uchida T, Oh-mura N, Kimura $\mathrm{K}$, Owa M, et al. Transient left ventricular apical ballooning without coronary artery stenosis: A novel heart syndrome mimicking acute myocardial infarction. Angina pectorismyocardial infarction investigations in Japan. J Am Coll Cardiol 2001;38:11-8.

4. Sharkey SW, Lesser JR, Zenovich AG, Maron MS, Lindberg $\mathrm{J}$, Longe TF, et al. Acute and reversible cardiomyopathy provoked by stress in women from the United States. Circulation 2005;111:472-9.

5. Wittstein IS, Thiemann DR, Lima JA, Baughman KL, Schulman SP, Gerstenblith G, et al. Neurohumoral features of myocardial stunning due to sudden emotional stress. N Engl J Med 2005;352:539-48.

6. Hurst RT, Prasad A, Askew JW 3rd, Sengupta PP, Tajik AJ. Takotsubo cardiomyopathy: A unique cardiomyopathy with variable ventricular morphology. JACC Cardiovasc Imaging 2010;3:641-9.

7. Prasad A, Lerman A, Rihal CS. Apical ballooning syndrome (tako-tsubo or stress cardiomyopathy): A mimic of acute myocardial infarction. Am Heart J 2008;155:408-17.

8. Akashi YJ, Goldstein DS, Barbaro G, Ueyama T. Takotsubo cardiomyopathy: A new form of acute, reversible heart failure. Circulation 2008;118:2754-62.

9. Prasad A. Apical ballooning syndrome: An important differential diagnosis of acute myocardial infarction. Circulation 2007;115:e56-9.

10. Bybee KA, Kara T, Prasad A, Lerman A, Barsness GW, Wright RS, et al. Systematic review: Transient left ventricular apical ballooning: A syndrome that mimics ST-segment elevation myocardial infarction. Ann Intern Med 2004;141:858-65.

11. Parodi G, Citro R, Bellandi B, Provenza G, Marrani M, Bossone E; Tako-tsubo Italian Network (TIN). Revised clinical diagnostic criteria for Tako-tsubo syndrome: The Tako-tsubo Italian Network proposal. Int $\mathbf{J}$ Cardiol 2014;172:282-3.

12. Sharkey SW, Windenburg DC, Lesser JR, Maron MS, Hauser RG, Lesser JN, et al. Natural history and expansive clinical profile of stress (tako-tsubo) cardiomyopathy. J Am Coll Cardiol 2010;55:333-41.

13. Campos FAD, Ritt LEF, Costa JPS, Cruz CM, Feitosa-Filho GS, Oliveira QB, et al. Factors associated with recurrence in Takotsubo syndrome: A systematic review. Arq Bras Cardiol 2020;114:477-83.

14. Chandy S, Dawson DK. Lifelong recurrent takotsubo cardiomyopathy: A case report. Eur Heart J Case Rep 2019;3:1-5.

15. Celebi H, Erdim R, Karabay KO, Yildirimturk O, Aytekin V. Recurrent left ventricular apical ballooning syndrome in a patient with pheochromocytoma. Int J Angiol 2012;21:63-8.

16. Arslan U, Tavil Y, Abaci A, Cengel A. Transient left ventricular apical ballooning syndrome: First series in Turkish patients. Anadolu Kardiyol Derg 2007;7:189-90.

17. Küçükdurmaz Z, Karapınar H, Oflaz MB, Gül I, Aydın G, Güneş H, et al. Takotsubo kardiyomiyopatisi hakkında klinik deneyimimiz ve ülkemizden bildirilen ilk olgu serisi. Turk Kardiyol Dern Ars 2013;41:212-7.

18. Deniz S, Bakal Ö, İnangil G, Şen H, Özkan S. Postoperatif evrede gelişen bir takatusubo kardiyomiyopatisi. Turk J Anaesthesiol Reanim 2015;43:47-9.

19. Yenerçă̆ M, Arslan U, Erdoğan G, Şeker OO, Yontar OC. A 99-year old patient with takotsubo cardiomyopathy recovering from cardiogenic shock. J Geriatr Cardiol 2019;16:578-9.

20. Ugurlucan M, Zorman Y, Ates G, Arslan AH, Yildiz Y, Karahan Zor A, et al. Takotsubo cardiomyopathy in a patient with multiple autoimmune disorders and hyperthyroidism. Res Cardiovasc Med 2013;2:145-8. 